\title{
Clinical Evaluation of Avelumab in the Treatment of Advanced Urothelial Carcinoma: Focus on Patient Selection and Outcomes
}

\author{
Jennifer E Ten Eyck $\mathbb{D}^{\prime}$, Navkirat Kahlon², Sonia Masih', Danae M Hamouda ${ }^{2}$, Firas G Petros $\mathbb{D}^{\prime}$ \\ 'Department of Urology, College of Medicine and Life Sciences, The University of Toledo, Toledo, OH, USA; ${ }^{2}$ Department of Hematology Oncology, \\ College of Medicine and Life Sciences, The University of Toledo, Toledo, OH, USA
}

Correspondence: Firas G Petros, Department of Urology, The University of Toledo, College of Medicine and Life Sciences, 3000 Arlington Ave., Mail Stop I09I, Toledo, OH, 436I4-2598, USA, Tel +| 419383 3584, Fax + I 419383 3785, Email firas.petros@utoledo.edu

Background: First-line therapy for treatment of advanced urothelial carcinoma includes combination platinum-based chemotherapies, though resistance and long-term toxicity concerns to these regimens cause limitations in progression-free survival and overall survival. Maintenance treatment with an alternative agent such as the PD-L1 inhibitor, avelumab (Bavencio ${ }^{\circledR}$ ), after initial chemotherapy has been shown to prolong overall survival. The aim of this review is to provide a landscape clinical use of avelumab in the treatment of advanced urothelial carcinoma with a focus on patient selection and outcomes.

Methods: This review includes the most up to date phases and results from clinical trials published in peer-reviewed journals.

Results: Three studies were included, one phase 1B trial, one phase 1B trial with 2 year follow-up, and one phase 3 trial. Patients receiving avelumab maintenance therapy at $10 \mathrm{mg} / \mathrm{kg}$ IV every two weeks had an overall better performance status, though those with an increased ECOG-PS, increased Bellmunt risk score, or failure of $\geq 3$ chemotherapies had poorer responses. Patients over the age of 65 had a higher ORR (18-25\%) compared to younger patients (13-14\%). Patients with PD-L1 positive tumors had a significantly increased CR median ORR (13.8\%), median PFS (5.7 months), and median 12-month OS rate (79.1\%) compared to control subjects receiving best supportive care $(1.2 \%, 2.1$ months, $60.4 \%$, respectively). TRAEs were seen in $86.7 \%$ of patients, with $32.4 \%$ of patients experiencing a $\geq$ grade 3 AE. The most common AE was IRR (32.4\%, zgrade $31.01 \%$ ) and irAE $25.6 \%$ of any grade, including various rashes and pruritus AEs, immune-related thyroid disorders, and immune related hepatitis. There were 3 reported treatmentrelated deaths $(0.05 \%)$. Ongoing phases of one of the trials is investigating the use of docetaxel and avelumab together after failure of one chemotherapy.

Conclusion: Avelumab as a maintenance therapy after platinum-based chemotherapy failure or in platinum-ineligible patients with advanced or metastatic urothelial carcinoma is an effective option with increased ORR, PFS, and OS with a similar safety profile to other chemotherapies. Ongoing studies currently in recruitment and active clinical trials will yield valuable insights into optimizing avelumab therapy in conjunction with chemotherapies and/or immunotherapies, better characterization of response for PD-L1 positive tumors, and a clearer insight into clinically validated prognostic factors to improve patient outcomes.

Keywords: avelumab, Bavencio ${ }^{\circledR}$, metastatic, advanced, urothelial carcinoma, patient outcomes

\section{Introduction}

First-line therapy for treatment of advanced urothelial carcinoma includes combination platinum-based chemotherapy such as gemcitabine plus cisplatin or dose-dense methotrexate, vinblastine, doxorubicin, and cisplatin (ddMVAC) for cisplatin eligible patients. ${ }^{1}$ For cisplatin ineligible patients, therapy includes gemcitabine with carboplatin or checkpoint inhibitor (CPI) with atezolizumab and pembrolizumab. ${ }^{2}$ Resistance to these chemotherapy regimens, however, causes limitations in progression-free survival and overall survival. Furthermore, long-term platinum-based chemotherapy is not feasible due to the increasing risk of toxicity over time. Median survival for cisplatin-based regimens has been reported as 14-15 months, while carboplatin-based regimens have been reported as 9-10 months. Disease progression for most 
patients usually occurs within 9 months of treatment initiation. ${ }^{3}$ The use of some alternative agents for maintenance treatment following chemotherapy has been shown to prolong overall survival for a subset of tumor types, but in general the prolongation of overall survival with these modalities has not been shown.

A continuous challenge with conventional chemotherapy is the development of tumor immunity. Gottesman et al proposed a mechanism of resistance for cisplatin, which functions by inducing apoptosis in cancer cells through DNA repair interference. ${ }^{4}$ These resistance mechanisms include changes in cellular uptake and efflux of the drug, increased biotransformation and detoxification in the liver, and an increase in DNA repair and anti-apoptotic mechanisms. Even so, tumor immunity continues to develop and contribute to limitation of survival prolongation. Maintenance treatment with an alternative agent after initial chemotherapy has been shown to prolong overall survival. Therefore, the aim of this review is to provide a landscape clinical use of avelumab in the treatment of advanced urothelial carcinoma with a focus on patient selection and outcomes.

\section{Methods}

For this review, literature was identified through PubMed and Embase databases with no limit on publication year or language. Search terms included "avelumab," "Bavencio ${ }^{\circledR}$," "bladder cancer," "malignant bladder cancer," "advanced bladder cancer," "urothelial," "urothelial bladder cancer," "advanced urothelial carcinoma," "metastatic urothelial carcinoma," "urothelial cancer cells," "urothelial abnormalities," "advanced urethra cancer," "malignant urethra cancer," "urethra carcinoma", "urethra disease," "urethra," and "urethra neoplasms." A total of 131 records were identified and screened for appropriate human trials as shown in Figure $1 .{ }^{5}$ Clinicaltrials.gov was cross-referenced using the terms "urothelial carcinoma" for disease and "avelumab" for other to ensure that no completed clinical trials were missed in the literature search. ${ }^{6}$

\section{Results}

\section{Studies of Avelumab in Advanced/Metastatic Urothelial Carcinoma}

Eight studies evaluating avelumab, an anti-programmed cell death ligand 1 (PD-L1) antibody, in advanced metastatic urothelial carcinoma were retrieved. Five of the eight studies were previously published phases of clinical trials whose latest phases were available for review. Two of the trials assessed avelumab alone at a dose of $10 \mathrm{mg} / \mathrm{kg} \mathrm{IV} \mathrm{every} \mathrm{two}$ weeks in patients who either did or did not have disease progression after first line platinum-based chemotherapy. The third study is investigating the use of docetaxel with avelumab after failure of one platinum-based chemotherapy. The tables in this review cover study design (Table 1) and significant outcomes (Table 2).

\section{Avelumab in Advanced Urothelial Carcinoma}

Avelumab in recent studies has been found to improve outcomes in patients with locally advanced and metastatic urothelial carcinoma. Patients treated with an avelumab dosing schedule of $10 \mathrm{mg} / \mathrm{kg}$ every two weeks until disease progression or unacceptable toxicity after 4 to 10 weeks of completing four to six cycles of chemotherapy with response or stable disease. For maintenance, median overall survival (OS) has been reported to be 21 months in a phase 3 trial with absolute improvement in OS by 7.1 months as compared to placebo by Powles et al. ${ }^{9}$ Patients with previously treated advanced/metastatic urothelial carcinoma platinum-based chemotherapy with no previous immunotherapy were found to have a median OS of 7 months in a phase 1B trial by Apolo et al. ${ }^{7}$

\section{FDA Approved Indications of Avelumab}

In 2017, avelumab was granted an accelerated approval from the Food and Drug Administration (FDA) for the treatment of patients with locally advanced or metastatic urothelial carcinoma who experience disease progression during or following platinum-containing chemotherapy, or who have disease progression within 12 months of neoadjuvant or adjuvant treatment with platinum-containing chemotherapy.

In 2020, avelumab has been approved for patients with advanced bladder cancer (regardless of PD-L1 tumor status) who do not progress (ie, achieve an objective response or stable disease) following platinum-based chemotherapy and are 


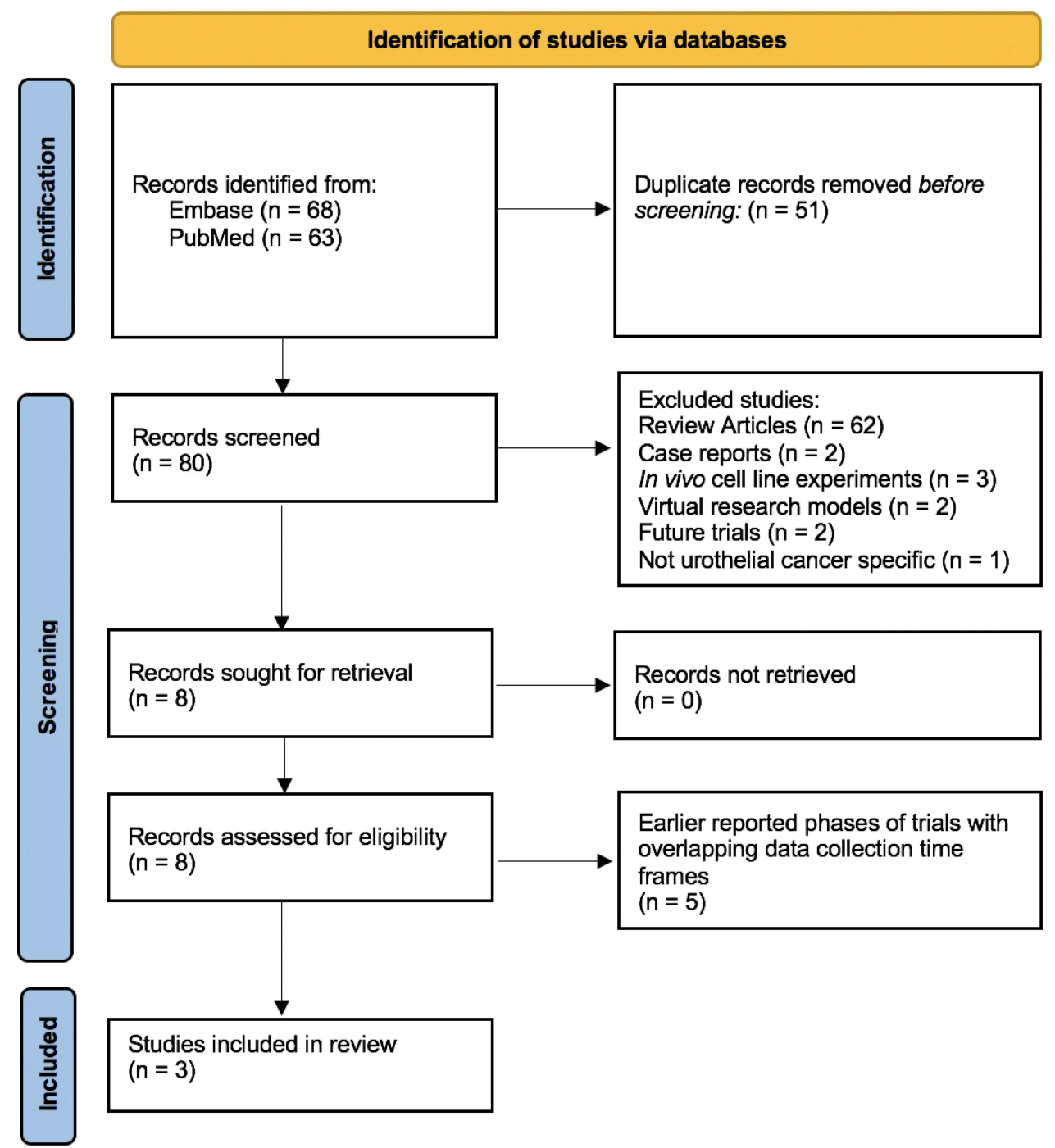

Figure I PRISMA flow diagram demonstrates identifications of studies via databases used for literature review, screening and final cohort of studies included in this review.

eligible to receive checkpoint inhibitor immunotherapy. Maintenance avelumab, rather than best supportive care alone, improved overall survival and progression-free survival (PFS) in a phase III trial. ${ }^{9}$

\section{Dosing}

Maintenance avelumab was administered at $10 \mathrm{mg} / \mathrm{kg}$ every two weeks until disease progression or unacceptable toxicity after 4 to 10 weeks of completing four to six cycles of chemotherapy whether a response or stable disease has been confirmed on radiographic imaging. The same dose has also been studied as a second line or subsequent line of treatment. The FDA more recently approved avelumab dose is $800 \mathrm{mg}$ administered as an intravenous infusion over 60 minutes every 2 weeks until disease progression or unacceptable toxicity as benefit:risk profiles for the two dosing regimens have been found to be similar. ${ }^{10}$

\section{Avelumab in Advanced Urothelial Carcinoma - Age}

The response of the elderly population to avelumab was overall very promising compared to that of younger populations. The study population in the JAVELIN solid tumor trial included two subgroups for age, less than 65 years $(\mathrm{n}=50)$ and $\geq 65$ years $(\mathrm{n}=111)$. Patients in the older subgroup experienced an overall higher overall response rate (ORR) $(18 \%$, CI $11-26 \%$ ) compared to the younger subgroup (14\%, CI 6-27\%). ${ }^{9}$ The Apolo et al study population included subjects $<75$ 
Table I Overview of Peer-Review Avelumab Trials Reviewed

\begin{tabular}{|c|c|c|c|c|c|c|c|c|c|c|c|c|}
\hline Paper & Name of Trial & $\begin{array}{l}\text { Type of } \\
\text { Study }\end{array}$ & $\begin{array}{l}\text { Agent and } \\
\text { Dosing }\end{array}$ & $\begin{array}{l}\text { Data } \\
\text { Collection } \\
\text { Time Point }\end{array}$ & Inclusion Criteria & $\begin{array}{l}\text { Patients, } \\
\text { n }\end{array}$ & $\begin{array}{l}\text { Age, } \\
\text { Median } \\
\text { Years }\end{array}$ & $\begin{array}{l}\text { Median } \\
\text { Duration } \\
\text { Follow- } \\
\text { Up }\end{array}$ & $\begin{array}{l}\text { Tumor PD-LI } \\
\text { Expression } \\
\text { ( } \geq 5 \% \text { Cut-Off) }\end{array}$ & & $\begin{array}{l}\text { Primary } \\
\text { Endpoint }\end{array}$ & $\begin{array}{l}\text { Secondary } \\
\text { Endpoint }\end{array}$ \\
\hline $\begin{array}{l}\text { Apolo } \\
\text { et al } \\
(2020)^{7}\end{array}$ & $\begin{array}{l}\text { JAVELIN Solid } \\
\text { Tumor } \\
\text { (NCT0I772004) }\end{array}$ & $\begin{array}{l}\text { Phase Ib, } \\
\text { open-label, } \\
2 \text { year } \\
\text { follow-up } \\
\text { update }\end{array}$ & $\begin{array}{l}\text { Avelumab (I0mg/ } \\
\text { kg Q2wks) }\end{array}$ & $\begin{array}{l}\text { September } 3 \text {, } \\
2014 \text { to } \\
\text { March } 15, \\
2016 \text { with } \\
\text { follow-up } \\
\text { through } \\
\text { April 10, 2018 }\end{array}$ & $\begin{array}{l}\text { Patients with previously } \\
\text { treated advanced/ metastatic } \\
\text { urothelial carcinoma } \\
\text { platinum based } \\
\text { chemotherapy or platinum- } \\
\text { ineligible with no previous } \\
\text { immunotherapy }\end{array}$ & $\begin{array}{l}249 \\
\text { patients }(7 \\
\text { platinum } \\
\text { naïve } \\
\text { included in } \\
\text { safety but } \\
\text { not } \\
\text { efficacy) }\end{array}$ & $\begin{array}{l}69.0(30- \\
89)\end{array}$ & $\begin{array}{l}31.9 \\
\text { months } \\
\text { (range 24- } \\
43 \\
\text { months) }\end{array}$ & $\begin{array}{l}\text { Positive, n (\%) } \\
\text { Negative, n (\%) } \\
\text { Not evaluable, } \\
\text { n (\%) }\end{array}$ & $\begin{array}{l}85 \\
(34.1) \\
135 \\
(54.2) \\
29 \\
(11.6)\end{array}$ & $\begin{array}{l}\text { Occurrence } \\
\text { of dose- } \\
\text { limiting } \\
\text { toxicities } \\
\text { during the } \\
\text { first } 3 \text { weeks } \\
\text { during dose- } \\
\text { escalation } \\
\text { and best } \\
\text { overall } \\
\text { response. }\end{array}$ & $\begin{array}{l}\text { End points } \\
\text { include } \\
\text { DOR, PFS, } \\
\text { OS, and } \\
\text { tumor PD- } \\
\text { LI } \\
\text { expression, } \\
\text { and safety, } \\
\text { including } \\
\text { post hoc } \\
\text { analysis. }\end{array}$ \\
\hline $\begin{array}{l}\text { Garje } \\
\text { et al } \\
(2020)^{8}\end{array}$ & $\begin{array}{l}\text { AVETAX } \\
\text { (NCT03575013) }\end{array}$ & $\begin{array}{l}\text { Phase Ib, } \\
\text { single } \\
\text { institution, } \\
\text { single arm } \\
\text { non- } \\
\text { randomized, } \\
\text { open label } \\
\text { prospective } \\
\text { trial }\end{array}$ & $\begin{array}{l}\text { Induction phase: } \\
\text { Avelumab (10 mg/ } \\
\mathrm{kg} \text { ) + Docetaxel } \\
\left(75 \mathrm{mg} / \mathrm{m}^{2}\right) \text { Q3wks } \\
\times 6 \text { cycles } \\
\text { Maintenance } \\
\text { phase: Avelumab } \\
10 \mathrm{mg} / \mathrm{kg} \mathrm{IV} \\
\text { Q2wks until } \\
\text { disease } \\
\text { progression or } \\
\text { toxicity }\end{array}$ & $\begin{array}{l}\text { October } 19, \\
2018 \text { to } \\
\text { February } 23, \\
2026\end{array}$ & $\begin{array}{l}\text { Either progression after at } \\
\text { least I platinum-containing } \\
\text { regimen OR ineligible for } \\
\text { cisplatin-based } \\
\text { chemotherapy OR locally } \\
\text { advanced or metastatic } \\
\text { bladder cancer with disease } \\
\text { progression within I2 } \\
\text { months of neoadjuvant or } \\
\text { adjuvant chemotherapy }\end{array}$ & 21 patients & $\begin{array}{l}\text { Ages 18-85 } \\
\text { eligible, no } \\
\text { information } \\
\text { on subjects } \\
\text { yet }\end{array}$ & 8 years & $\begin{array}{l}\text { Not reported at } \\
\text { this time }\end{array}$ & & Safety & $\begin{array}{l}\text { ORR, PFS, } \\
\text { and OS. }\end{array}$ \\
\hline $\begin{array}{l}\text { Powles } \\
\text { et al } \\
(2020)^{9}\end{array}$ & $\begin{array}{l}\text { JAVELIN } \\
\text { Bladder } 100 \\
\text { (NCT02603432) }\end{array}$ & $\begin{array}{l}\text { Phase 3, } \\
\text { open- } \\
\text { labeled } \\
\text { randomized } \\
\text { controlled } \\
\text { trial }\end{array}$ & $\begin{array}{l}\text { Treatment group: } \\
\text { maintenance } \\
\text { therapy with } \\
\text { avelumab at a dose } \\
\text { of } 10 \mathrm{mg} / \mathrm{kg} \text { IV } \\
\text { Q2wks plus best } \\
\text { supportive care; } \\
\text { Control group: } \\
\text { best supportive } \\
\text { care alone }\end{array}$ & $\begin{array}{l}\text { May II, } 2016 \\
\text { to } \\
\text { October 21, } \\
2019\end{array}$ & $\begin{array}{l}\text { Patients with unresectable } \\
\text { locally advanced or } \\
\text { metastatic urothelial cancer } \\
\text { who did not have disease } \\
\text { progression with first-line } \\
\text { chemotherapy (four to six } \\
\text { cycles of gemcitabine plus } \\
\text { cisplatin or carboplatin) }\end{array}$ & $\begin{array}{l}\text { Treatment } \\
\text { group: } 350 \\
\text { patients; } \\
\text { Control } \\
\text { group: } 350 \\
\text { patients }\end{array}$ & $68(37-90)$ & $\begin{array}{l}\text { Not } \\
\text { reported }\end{array}$ & $\begin{array}{l}\text { Treatment } \\
\text { group PD-LI } \\
\text { positive, } \mathbf{n} \\
\text { Control group } \\
\text { PD-LI } \\
\text { positive, } n\end{array}$ & $\begin{array}{l}189 / 328 \\
\text { patients } \\
(57.6 \%) \\
169 / 300 \\
\text { patients } \\
(56.3 \%)\end{array}$ & $\begin{array}{l}\text { OS, assessed } \\
\text { among } \\
\text { overall } \\
\text { randomized } \\
\text { population } \\
\text { and among } \\
\text { those with } \\
\text { tumors } \\
\text { positive for } \\
\text { PD-LI. }\end{array}$ & $\begin{array}{l}\text { PFS and } \\
\text { safety. }\end{array}$ \\
\hline
\end{tabular}

Abbreviations: DOR, duration of response; IV, intravenous; NCT, national clinical trial; ORR, overall response rate; OS, overall survival; PD-LI, programmed cell death ligand I; PFS, progression free survival; O2wk, every two weeks; Q3wks, every 3 weeks. 
Table 2 Published Avelumab Patient Outcomes of Reviewed Papers

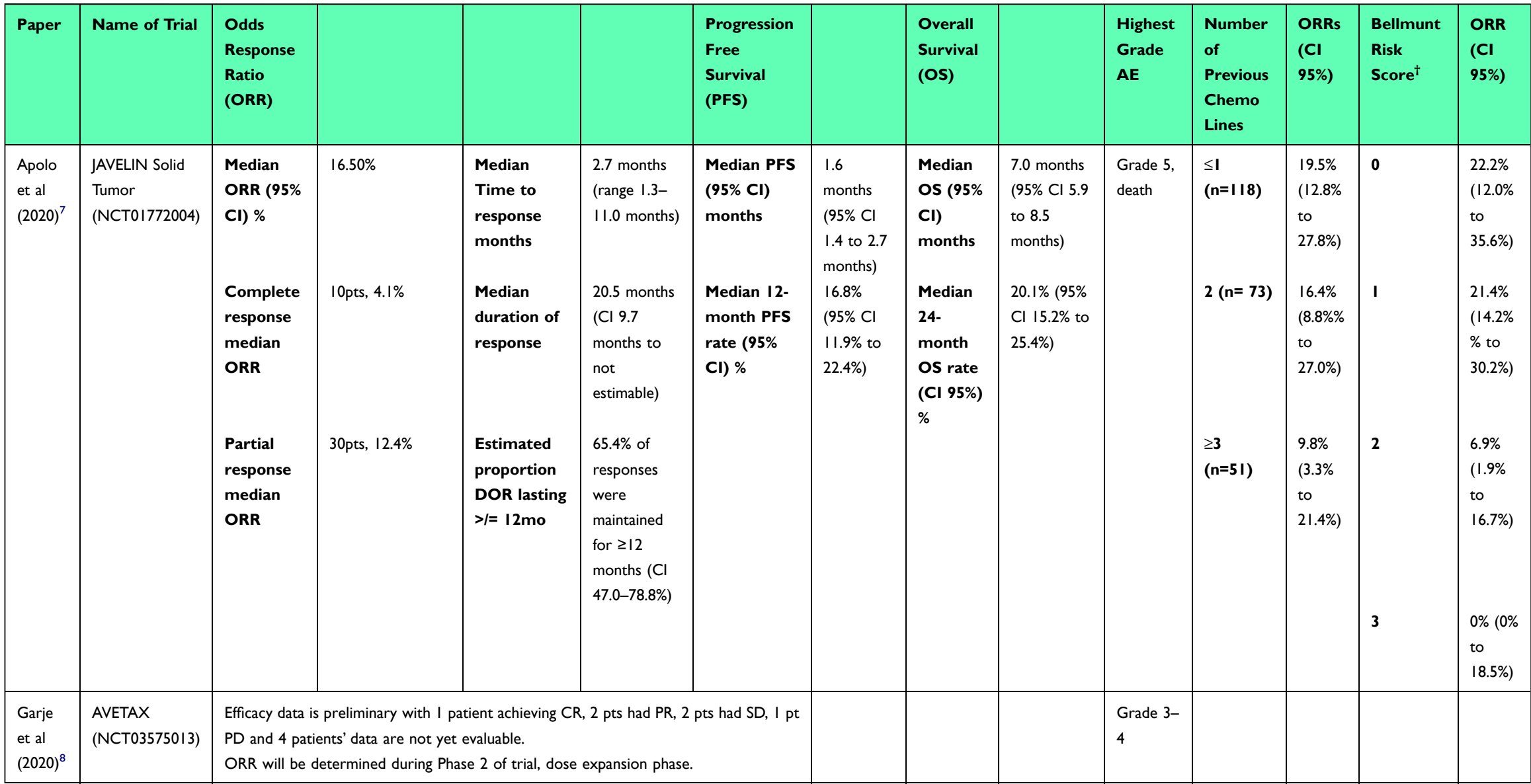

(Continued) 
Table 2 (Continued).

\begin{tabular}{|c|c|c|c|c|c|c|c|c|c|c|c|c|c|c|}
\hline Paper & Name of Trial & $\begin{array}{l}\text { Odds } \\
\text { Response } \\
\text { Ratio } \\
\text { (ORR) }\end{array}$ & & & & $\begin{array}{l}\text { Progression } \\
\text { Free } \\
\text { Survival } \\
\text { (PFS) }\end{array}$ & & $\begin{array}{l}\text { Overall } \\
\text { Survival } \\
\text { (OS) }\end{array}$ & & $\begin{array}{l}\text { Highest } \\
\text { Grade } \\
\text { AE }\end{array}$ & $\begin{array}{l}\text { Number } \\
\text { of } \\
\text { Previous } \\
\text { Chemo } \\
\text { Lines }\end{array}$ & $\begin{array}{l}\text { ORRs } \\
\text { (Cl } \\
95 \%)\end{array}$ & $\begin{array}{l}\text { Bellmunt } \\
\text { Risk } \\
\text { Score }^{\dagger}\end{array}$ & $\begin{array}{l}\text { ORR } \\
\text { (CI } \\
95 \%)\end{array}$ \\
\hline $\begin{array}{l}\text { Powles } \\
\text { et al } \\
(2020)^{9}\end{array}$ & $\begin{array}{l}\text { JAVELIN } \\
\text { Bladder 100 } \\
\text { (NCT02603432) }\end{array}$ & $\begin{array}{l}\text { Median } \\
\text { ORR (95\% } \\
\text { CI) \% } \\
\\
\text { CR } \\
\text { median } \\
\text { ORR } \\
\text { number } \\
\text { (\%) } \\
\\
\\
\text { PR } \\
\text { median } \\
\text { ORR, } \\
\text { number } \\
\text { (\%) } \\
\\
\\
\text { PD-LI } \\
\text { positive } \\
\text { CR } \\
\text { median } \\
\text { ORR, } \\
\text { number } \\
\text { (\%) }\end{array}$ & $\begin{array}{l}9.7(6.8 \text { to } 13.3) \text { vs } \\
\text { control I.4 (0.5 to } \\
\text { 3.3); Stratified OR } \\
\text { (95\% Cl) } 7.46 \\
\text { (2.82 to } 24.45) \\
\text { 21 (6.0) vs control } \\
3(0.9) \\
\text { 13 (3.7) vs control } \\
2 \text { (0.6) } \\
\end{array}$ & $\begin{array}{l}\begin{array}{l}\text { Median } \\
\text { Time to } \\
\text { response, } \\
\text { months } \\
\text { (range) }\end{array} \\
\text { Median } \\
\text { DOR } \\
\text { (response) } \\
\text { weeks }\end{array}$ & $\begin{array}{l}2.0 \text { (1.7 to } \\
16.4) \text { vs } \\
\text { control } 2.0 \\
\text { (1.8 to } 7.0) \\
\\
24.9 \text { weeks } \\
(2.0 \text { to } 159.9) \\
\text { vs control } \\
\text { 13.I weeks } \\
(0.1 \text { to } 155.6) \\
\\
44 \text { (12.6) vs } \\
\text { control } 46 \\
(13.1) \\
\end{array}$ & $\begin{array}{l}\text { Median PFS } \\
(95 \% \mathrm{Cl}) \\
\text { months } \\
\\
\text { PD-LI } \\
\text { positive } \\
\text { Median PFS } \\
(95 \% \text { Cl) } \\
\text { months } \\
\\
\\
\text { PD-LI } \\
\text { negative } \\
\text { Median PFS } \\
\text { (95\% Cl) } \\
\text { months }\end{array}$ & $\begin{array}{l}3.7 \\
\text { months } \\
(3.5 \text { to } \\
5.5) \text { vs } \\
\text { control } \\
2.0 \\
\text { months } \\
(1.9 \text { to } \\
2.7) \\
5.7 \\
\text { months } \\
(3.7 \text { to } \\
7.4) \text { vs } \\
\text { control } \\
2.1 \\
\text { months } \\
(1.9 \text { to } \\
3.5) \\
3.0 \\
\text { months } \\
\text { (2.0 to } \\
3.7) \text { vs } \\
\text { control } \\
1.9 \\
\text { months } \\
\text { (1.9 to } \\
2.1)\end{array}$ & $\begin{array}{l}\text { Median } \\
\text { 12- } \\
\text { month } \\
\text { OS rate } \\
\text { (CI 95\%) } \\
\% \\
\text { PD-LI } \\
\text { positive } \\
\text { median } \\
\text { I2- } \\
\text { month } \\
\text { OS (CI } \\
95 \% \% \\
\text { PD-LI } \\
\text { negative } \\
\text { Median } \\
\text { OS (CI } \\
95 \%) \\
\text { months }\end{array}$ & $\begin{array}{l}21.4 \text { months } \\
\text { (18.9 to } \\
26.1) \text { vs } \\
\text { control } 14.3 \\
\text { months } \\
(12.9 \text { to } \\
17.9) \\
71.3 \%(66.0 \\
\text { to } 76.0) \text { vs } \\
\text { control } \\
58.4 \%(52.7 \\
\text { to } 63.7)\end{array}$ & $\begin{array}{l}\text { Grade 5, } \\
\text { death }\end{array}$ & & & & \\
\hline
\end{tabular}

Note: ${ }^{\dagger}$ Bellmunt risk score includes ECOG performance status $>0$, hemoglobin $<10 \mathrm{~g} / \mathrm{dL}$, and presence of liver metastasis.

Abbreviations: AE, adverse event; chemo, chemotherapy; Cl, confidence interval; CR, complete response; DOR, duration of response; ECOG, Eastern Cooperative Oncology Group; ORR, overall response rate; OS, overall survival PD, progressive disease; PD-LI, programmed cell death ligand I; PFS, progression free survival; PR, partial response; PS, performance status; pts, patients; SD, stable disease. 
years old $(\mathrm{n}=176,70.7 \%)$ and $\geq 75$ years old $(\mathrm{n}=73,29.2 \%)$. Similarly, to the JAVELIN solid tumor trial, there was a higher ORR to avelumab in the older subgroup (25.0\%) compared to the younger subgroup (13.2\%, CI 8.6-19.2\%). The most common treatment-related adverse events in the elderly subgroup in this study was renal and urinary disorders (31.5\%) and infusion-related reactions $(28.8 \%){ }^{7}$ This data demonstrates improved response and survival in older patients.

\section{Avelumab in Advanced Urothelial Carcinoma - Performance Status}

Overall, studies showed that patients with a better performance status had better response to avelumab. In the JAVELIN solid tumor study, patients with Eastern Cooperative Oncology Group (ECOG) performance status $0(\mathrm{n}=56)$ experienced an ORR of $23 \%$ (CI 13-36\%) versus $13 \%$ (CI 8-21) in those with an ECOG $\geq 1(\mathrm{n}=105)$. The Apolo et al study also demonstrated that patients with a better PS had greater benefit from avelumab therapy compared to those with a poorer PS. Those with an ECOG 0 had an ORR of $19.0 \%$ versus those with ECOG $\geq 1$ who had an ORR of $15.2 \%$. In the same study, for patients with a Bellmunt prognostic (or risk) score of 0, 1, 2 or 3, ORRs were $22.2 \%$ (CI 12.0-35.6\%), 21.4\% (14.2-30.2\%), 6.9\% (1.9-16.7\%) and $0 \%(0-18.5 \%)$, respectively. ${ }^{7}$

\section{Avelumab in Advanced Urothelial Carcinoma - PD-LI Status}

PD-L1 expression as a predictive biomarker for response to immunotherapy has its limitations. It has been measured in a variable fashion in tumor cells or tumor-infiltrating cells. ${ }^{11}$ Also, the thresholds are variable within and across tumor subtypes. In the context of avelumab and urothelial cancer, the two major studies ie, Phase 1B JAVELIN Solid Tumor by Apolo et al and JAVELIN Bladder 100 by Powles et al, included both PD-L1 positive and negative patients but the assays used and hence the definition of PD-L1 positivity was different. ${ }^{7,9}$

Apolo et al defined PDL1 positivity as $>/=5 \%$, using Dako PD-L1 IHC 73-10 pharmDx PD-L1 assay. 34.1\% patients were PD-L1 positive (+), 54.2\% were PD-L1 negative (-) and 11.6\% were not evaluable. Outcomes for subgroup analysis according to PD-L1 status were included in supplemental material. In the PD-L1+ group, the confirmed ORR (95\% CI) was $23.8 \%$ (15.2-34.3\%) and in the PD-L1- group was 12.3\% (7.2-19.2\%). Median PFS (95\% CI) in PD-L1+ group was 2.2 months (1.4-4.11\%) and 1.5 months (1.4-2.4\%) in PD-L1- group. However, 12-month PFS rate (95\% CI), in PD-L1+ patients was lower ie $14.6 \%(8.8-21.9 \%)$ as compared to $23.9 \%$ (14.2-35.0\%) in PD-L1- patients. Median OS (95\% CI) in months was $8.41(6.0-11.3 \%)$ in PD-L1+ group and $6.5(5.3-10.1 \%)$ in the PD-L1- group. 24-month OS rate (95\% CI), \% was 24.3\% (15.6-34.0\%) in PD-L1+ patients vs 17.9\% (11.8-25.0\%) in PD-L1- patients. Overall, patients with PD-L1+ had higher ORR, better median PFS and better OS as compared to PD-L1 negative patients. It is approved for use regardless of PD-L1 status. ${ }^{7}$

In JAVELIN Bladder 100 by Powles et al, PD-L1 expression was assessed in tumor samples by means of the Ventana PD-L1 assay (SP263, Ventana Medical Systems). Patients were classified as having PD-L1-positive status if at least one of the following three criteria were met: at least $25 \%$ of tumor cells stained for PD-L1, at least $25 \%$ of immune cells stained for PD-L1 if more than $1 \%$ of the tumor area contained immune cells, or $100 \%$ of immune cells stained for PDL1 if no more than $1 \%$ of the tumor area contained immune cells. $51.1 \%$ had PD-L1-positive tumors in this study. The patient characteristics were balanced between the two treatment groups (placebo and avelumab maintenance group) for the PD-L1-positive population. This study allowed a crossover to receive immunotherapy as subsequent anticancer drug therapy. Subsequent treatment was given to $42.3 \%$ in the avelumab group and $61.7 \%$ in the control group, including an anti-PD-1 or anti-PD-L1 antibody in $6.3 \%$ in the avelumab group and $43.7 \%$ in the control group. Even with a significant number of patients receiving immunotherapy on progression in the placebo arm, avelumab in a maintenance setting, significantly prolonged overall survival in the PD-L1-positive population with overall survival at 1 year of $79.1 \%$ in the avelumab group and $60.4 \%$ in the control group (hazard ratio, $0.56 ; 95 \% \mathrm{CI}, 0.40-0.79 ; \mathrm{P}<0.001$ ). The median progression-free survival in avelumab and placebo treated patients was 5.7 months and 2.1 months, respectively, in the PD-L1-positive population (hazard ratio, 0.56; 95\% CI, 0.43-0.73). ${ }^{9}$

\section{Avelumab in Advanced Urothelial Carcinoma - Patient Safety}

Overall, no new toxicity signals were found in any of the studies included in the review. 
Garje et al, in published abstract with combined chemoimmunotherapy, reported 1 dose limiting toxicity (neutropenic fever) in addition to the most common grade 3-4 adverse events (AE) of febrile neutropenia, urinary tract infection, and confusion. ${ }^{8}$

Adverse events from Apolo et al and Powles et al are summarized in Table 3. The most common treatment-related adverse events (TRAE) (>10\%) of any grade from both trials include fatigue, various immune related rashes and pruritic $\mathrm{AE}$, diarrhea, renal events (including increased creatinine and renal/urinary disorders), and immune-related thyroid disorders (including hypothyroidism, hyperthyroidism). ${ }^{7,9}$

In the Apolo et al article $71.1 \%$ patients were found to have treatment-related adverse effects of any grade, $11.6 \%$ had TRAEs of grade 3 or higher with fatigue being most common. Treatment-related death occurred in one patient $(0.4 \%)$, due to pneumonitis. The most common immune-related adverse events (irAE) (any grade) were immune-related rash (11.2\%), including various rash/pruritus $\mathrm{AE}$ and immune related thyroid disorders (13, 5.2\%), including hypothyroidism, hyperthyroidism and blood thyroid-stimulating hormone increase). In an exploratory post hoc analysis, frequency and extent of infusion related reactions (IRR) in high-risk patient subgroups (such as patients with renal insufficiency, upper tract disease, liver metastases) were similar to the overall population in study compared with the overall population. $15.7 \%$ of patients discontinued treatment due to adverse effects in this study. ${ }^{9}$

The Powles et al safety population, defined as any patient who received one or more doses of avelumab, also noted common TRAEs $(>10 \%)$ of arthralgia, asthenia, constipation, back pain, nausea, pyrexia, anorexia, cough, vomiting, anemia, and hematuria. The incidence of adverse events from any cause was $98.0 \%$ in the avelumab group and $77.7 \%$ in the control group; the incidence of adverse events of grade 3 or higher was $47.4 \%$ and $25.2 \%$, respectively. In the avelumab group, median duration of trial treatment was 24.9 weeks and adverse events led to treatment discontinuation in $11.9 \%$ patients. Death was attributed by the investigator to the toxicity of trial treatment in two patients $(0.6 \%)$ in the avelumab group. $29 \%$ of patients had irAE $7.0 \%$ with grade 3 events. No grade 4 or fatal irAE occurred. The most frequent irAE was thyroid disorders (12.2\%). $9 \%$ of patients required high-dose glucocorticoids ( $\geq 40 \mathrm{mg}$ total daily dose of prednisone or equivalent) for irAE in avelumab-treated patients. ${ }^{9}$

\section{Future Directions}

Continued research is needed in the AVETAX and JAVELIN Bladder 100 clinicals trials as the research progresses through their respective clinical trial phases, including particular attention to the response of PD-L1 positive tumors

Table 3 Combined Summary of Adverse Events in Apolo et al and Powles et al for 593 Patients ${ }^{7,9}$

\begin{tabular}{|c|c|c|}
\hline TRAE, $\mathbf{n}$ & Any & $\geq$ Grade 3 \\
\hline & 514 patients $(86.7 \%)$ & I 92 patients (32.4\%) \\
\hline $\begin{array}{l}\text { Treatment related } \\
\text { death, } \mathrm{n}\end{array}$ & $\begin{array}{l}3 \text { patients }(0.05 \%) \\
\text { Severe pneumonitis } \\
\text { Sepsis s/p UTI and possible blood infection after II avelumab treatments } \\
\text { Ischemic stroke within } 100 \text { days of first avelumab treatment, which followed VT, PE, } \\
\text { and acute MI }\end{array}$ & $\mathrm{n} / \mathrm{a}$ \\
\hline IRR, $n$ & 192 patients (32.4\%) & 6 patients (1.01\%) \\
\hline irAE, n & 152 patients $(25.6 \%)$ & 36 patients $(6.07 \%)$ \\
\hline Most common irAE & $\begin{array}{l}\text { Immune-related rash, including various rashes and pruritus AEs } \\
\text { II } 4 \text { (19.2\%) } \\
\text { Immune-related thyroid disorders, including hypothyroidism, hyperthyroidism, and } \\
\text { increased serum TSH } \\
83(14.0 \%)\end{array}$ & $\begin{array}{l}\text { Immune related hepatitis } \\
10 \text { patients }(1.7 \%)\end{array}$ \\
\hline $\begin{array}{l}\text { Most common } \geq 3 \\
\text { TRAE, } n\end{array}$ & $\mathrm{n} / \mathrm{a}$ & Fatigue 68 patients ( $11.5 \%)$ \\
\hline
\end{tabular}

Abbreviations: AE, adverse event; irAE, immune related adverse event; IRR, infusion related reaction; MI, myocardial infarction; PE, pulmonary embolism; s/p, status post; TRAE, treatment related adverse event; TSH, thyroid stimulating hormone; UTI, urinary tract infection; VT, venous thrombosis. 
versus controls. In June 2020, avelumab was granted the FDA approval to change the approved dosage from $10 \mathrm{mg} / \mathrm{kg} \mathrm{IV}$ every two weeks to a flat-dose of $800 \mathrm{mg} I V$ every two weeks per pharmacological models analyzing exposure-safety and exposure-efficacy models. ${ }^{10,12}$ The flat-rate dosage has yet to be implemented in published clinical trials and will need further verification. The prognostic model for survival in post-platinum patients with metastatic urothelial carcinoma (based on ECOG performance status, liver metastasis, platelet count, neutrophil-to-lymphocyte ratio, and lactate dehydrogenase) also needs further validation with avelumab based trials. It is also important to account for flat-rate versus body-weight dosing and comparing its prognostic outcomes versus the Bellmunt risk score. ${ }^{13}$

There are currently 19 active or actively recruiting trials on clinicaltrials.gov for studies involving avelumab and urothelial carcinoma. Many of the active trials are now focusing on the optimal duration of avelumab therapy, combining avelumab with other chemotherapy agents and/or immune therapies, and assessing the efficacy of avelumab therapy after other immune checkpoint inhibitor therapies have failed. Several of these trials have faced delays due to the SARS-CoV-19 pandemic and will hopefully be able to progress at an appropriate pace as the pandemic slows. ${ }^{6}$

\section{Discussion}

In 2017, avelumab was granted FDA approval for the treatment of patients with locally advanced or metastatic urothelial carcinoma who experience disease progression during or following platinum-containing chemotherapy, or who have disease progression within 12 months of neoadjuvant or adjuvant treatment with platinum-containing chemotherapy. In 2020, avelumab was approved for patients with advanced bladder cancer (regardless of PD-L1 tumor status) who do not progress (ie, achieve an objective response or stable disease) following platinum-based chemotherapy and are eligible to receive checkpoint inhibitor immunotherapy. It has been found to be both an efficacious and tolerable option in those settings. In maintenance settings, it improved ORRs, median PFS, and median OS even with subsequent crossover in the placebo arm to immunotherapy on progression. Benefit was seen in both PD-L1 positive and negative patients. No new toxicity signals were found with avelumab use in urothelial cancer.

Current clinical trials are continuing to assess the efficacy of avelumab on its own as a maintenance therapy with and without disease progression and in combining avelumab with other chemotherapy and immunotherapy options. These trials will be critical in creating future guidelines for advanced or metastatic urothelial carcinoma and how to more effectively treat PD-L1 positive tumors.

\section{Conclusion}

In summary, avelumab is an effective and well-tolerated regimen for patients with advanced urothelial cancer who have not progressed on chemotherapy, as well as for patients with progression of disease after receiving platinum-containing chemotherapy. It is now the standard of care in these two settings.

\section{Abbreviations}

AE, adverse event; CI, confidence interval; CR, complete response; DOR, duration of response; ECOG, Eastern Cooperative Oncology Group; FDA, Food and Drug Administration; irAE, immune related adverse event; IRR, Infusion related reaction; IV, intravenous; MI, myocardial infarction; n/a, not applicable; NCT, national clinical trial; ORR, overall response rate; OS, overall survival; PD, progressive disease; PD-L1, programmed cell death ligand 1; PE, pulmonary embolism; PFS, progression free survival; PR, partial response; PS, performance status; Q2wk, every two weeks; SD, stable disease; s/p, status post; TRAE, treatment related adverse event; TSH, thyroid stimulating hormone; UTI, urinary tract infection; VT, venous thrombosis.

\section{Acknowledgments}

Thank you to Margaret Hoogland, MLS, AHIP at The University of Toledo Library for assistance in the literature search.

\section{Disclosure}

The authors report no conflicts of interest in this work. 


\section{References}

1. NCCN. NCCN clinical practice guidelines in oncology (NCCN guidelines) for bladder cancer; 2021. Available from: https://www.nccn.org/ professionals/physician gls/pdf/bladder.pdf. Accessed July 27, 2021.

2. Resch I, Shariat SF, Gust KM. PD-1 and PD-L1 inhibitors after platinum-based chemotherapy or in first-line therapy in cisplatin-ineligible patients: dramatic improvement of prognosis and overall survival after decades of hopelessness in patients with metastatic urothelial cancer. Memo. 2018;11 (1):43-46. doi:10.1007/s12254-018-0396-y

3. von der Maase H, Hansen SW, Roberts JT, et al. Gemcitabine and cisplatin versus methotrexate, vinblastine, doxorubicin, and cisplatin in advanced or metastatic bladder cancer: results of a large, randomized, multinational, multicenter, phase III study. J Clin Oncol. 2000;18:3068-3077. doi:10.1200/JCO.2000.18.17.3068

4. Gottesman MM, Fojo T, Bates SE. Multidrug resistance in cancer: role of ATP-dependent transporters. Nat Rev Cancer. 2002;2:48-58.

5. Page MJ, McKenzie JE, Bossuyt PM, et al. The PRISMA 2020 statement: an updated guideline for reporting systematic reviews. BMJ. 2021;372: n71. doi:10.1136/bmj.n71

6. ClinicalTrials.gov; 2021. Available from: https://clinicaltrials.gov. Accessed September 12, 2021.

7. Apolo AB, Ellerton JA, Infante JR, et al. Avelumab as second-line therapy for metastatic, platinum-treated urothelial carcinoma in the phase Ib JAVELIN solid tumor study: 2-year updated efficacy and safety analysis. J Immunother Cancer. 2020;8:e01246. doi:10.1136/jitc-2020-001246

8. Garje R, Ginader T, Laux DE, et al. A phase Ib study of combination of avelumab and taxane-based chemotherapy in platinum refractory or ineligible metastatic urothelial cancer (AVETAX study). J Clin Oncol. 2020;38(6_suppl):487. doi:10.1200/JCO.2020.38.6_suppl.487

9. Powles T, Park SH, Voog E, et al. Avelumab maintenance therapy for advanced or metastatic urothelial carcinoma. $N$ Engl J Med. 2020;383:1218-1230. doi:10.1056/NEJMoa2002788

10. Novakovic AM, Wilkins JJ, Dai H, et al. Changing body weight-based dosing to a flat dose for avelumab in metastatic Merkel cell and advanced urothelial carcinoma. Clin Pharmacol Ther. 2020;107(3):588-596. doi:10.1002/cpt.1645

11. Davis AA, Patel VG. The role of PD-L1 expression as a predictive biomarker: an analysis of all US Food and Drug Administration (FDA) approvals of immune checkpoint inhibitors. $J$ Immunother Cancer. 2019;7:278. doi:10.1186/s40425-019-0768-9

12. U.S. Food and Drug Administration. FDA approves avelumab for urothelial carcinoma maintenance treatment. Silver Spring (MD): U.S. Food and Drug Administration; 2020. Available from: https://www.fda.gov/drugs/drug-approvals-and-databases/fda-approves-avelumab-urothelial-carcinoma -maintenance-treatment. Accessed January 27, 2022.

13. Sonpavde G, Manitz J, Gao C, et al. Five-factor prognostic model for survival of post-platinum patients with metastatic urothelial carcinoma receiving PD-L1 inhibitors. $J$ Urol. 2020;204(6):1173-1179. doi:10.1097/JU.0000000000001199

Cancer Management and Research is an international, peer-reviewed open access journal focusing on cancer research and the optimal use of preventative and integrated treatment interventions to achieve improved outcomes, enhanced survival and quality of life for the cancer patient. The manuscript management system is completely online and includes a very quick and fair peer-review system, which is all easy to use. Visit http://www.dovepress.com/testimonials.php to read real quotes from published authors. 